\title{
Vacina contra o HPV ou contra o câncer de colo uterino?
}

Carta ao editor

Correspondência:

E-mail: eddiemurta@mednet.com.br

Prezado editor,

Cumprimentamos aos autores do editorial da Revista Brasileira de Ginecologia e Obstetrícia, volume 29, número 6, Vacinas Profiláticas para o $\mathrm{HPV}^{1}$. Ao abordar assunto de tamanho interesse de nossa especialidade, atual e de abrangências médica e econômica mundiais, Derchain e Sarian ${ }^{1}$ conduziram este texto de modo claro, objetivo e profundo. Baseado em publicações de revistas de alto impacto, chegaram a uma conclusão de maturidade científica sobre o tema.

Poderia se acrescentar à estas fontes, o trabalho publicado pelo FUTURE II Study Group ${ }^{2}$, que mostra os resultados do uso da vacina quadrivalente 36 meses após a aplicação. Demonstra-se um bom efeito na prevenção do papilomavírus humano (HPV) nestes primeiros anos; no entanto, a proteção contra as lesões precursoras do câncer de colo uterino diminui muito após este período. Observa-se também, na Tabela 3, que os resultados nos grupos (de população) não suscetíveis mostram uma eficácia da vacina com intervalo de confiança muito variável na avaliação contra os HPVs
16 e 18, e na freqüência de neoplasia intra-epitelial cervical graus II e III e no adenocarcinoma in situ. Portanto, é muito prematuro associar esta vacina a prevenção do câncer do colo uterino no estágio em que se encontra.

Em um Word Report publicado no Lancet, Udesky ${ }^{3}$ cita outros pontos em relação a esta vacina, como exemplo e não recomendação a adolescentes do sexo masculino, por não ter sido ainda demonstrado sua efetividade e segurança, e ressalva a importância de uma boa educação sexual. Além disso, ressalta que um funcionário do governo do Texas é agora um lobista de uma indústria farmacêutica produtora de uma das vacinas do HPV, e também como é criticável a maneira como as indústrias têm conduzido suas campanhas de vacinação induzindo a sua obrigatoriedade.

Devido à qualidade deste editorial, sugiro sua reprodução, utilizando também meios não científicos de divulgação com uma linguagem menos científica, mas que mantenha a conclusão final, para que sirva de base de discussão, não só para nossas colegas tocoginecologistas, mas também para os de outras especialidades.

\section{Referências}

1. Derchain SFM, Sarian LOZ. Vacinas profiláticas para o HPV. Rev Bras Ginecol Obstet. 2007;29(6):281-4.

2. Future II Study Group. Quadrivalent vaccine against human papillomavirus to prevent high-grade cervical lesions. N Engl J Med. 2007;356(19): 1915-27.
3. Udesky L. Push to mandate HPV vaccine triggers backlash in USA. Lancet. 2007;369(9566):979-80. 